\title{
Wound Healing Potential Of Water And Ethanol Extract Of Fresh Leaves And Bark Ofgambia Albidum In Albino Rats
}

\author{
Aloh Godwin Sunday ${ }^{1}$,Obeagu Emmanuel Ifeanyi ${ }^{2}$,Onu Felicity Uzor $^{3}$ \\ 1.Lecturer,Department of Biochemistry,Michael Okpara University of Agriculture,Umudike,Abia State,Nigeria. \\ 2.Diagnostic Laboratory Unit,University Health Services Department, Michael Okpara University of \\ Agriculture,Umudike,Abia State,Nigeria. \\ 3.Department of Biochemistry,Ebonyi State University,Abakaliki,Nigeria.
}

\begin{abstract}
Water and ethanol extracts of Gambia albidumleaf and bark were studied for their wound healing potential. The biochemical parameters studied were: serum total protein, monoamine oxidase (MAO) activity, ascorbic acid, protease activity and cysteine. The rats were grouped into control $(C)$ on which about $20 \mathrm{~mm}$ wounds were made but not treated, while groups $A_{1}, A_{2}, B_{1}$ and $B_{2}$ were treated with $500 \mathrm{mg} / \mathrm{kg}$ body weight of the extracts for 10 days. Olive oil suspensions of the extracts were also applied topically to the wounds throughout the period of the study. The mean percentage reductions of the wound diameters were: control (43.60\%); $A_{I}$ (treated with water extract of bark- $\left.65.30 \%\right) ; A_{2}$ (treated with ethanol extract of bark $\left.-76.79 \%\right)$; $B_{1}$ (treated with water extract of leaves $-53.96 \%$ ); and $B_{2}$ (treated with ethanol extract of leaves $-60.84 \%$ ). The serum levels of the parameters after administering water extract of the leaves were: total protein $(0.686 \pm 0.000 \mathrm{mg} / 100 \mathrm{ml}), \quad M A O \quad(1.325 \pm 0.023 \mu / \mathrm{l})$, ascorbic acid $(51.50 \pm 0.736 \mathrm{mg} / 100 \mathrm{ml})$, protease $(1.880 \pm 0.047 \mu \mathrm{g} / 100 \mathrm{ml})$ and cysteine $(22.22 \pm 0.686 \mathrm{mg} / 100 \mathrm{ml})$. The mean levels after water extracts of the bark were: total protein $(0.754 \pm 0.026 \mathrm{mg} / 100 \mathrm{ml})$, MAO $(1.103 \pm 0.195 \mu / \mathrm{l})$, ascorbic acid $(50.08 \pm 2.383 \mathrm{mg} / 100 \mathrm{ml})$, protease $(1.743 \pm 0.063 \mu \mathrm{g} / 100 \mathrm{ml})$, and cysteine $(23.37 \pm 0.635 \mathrm{mg} / 100 \mathrm{ml})$. The mean levels in the animals given ethanol extract of the leaves were: total protein $(0.767 \pm 0.012 \mathrm{mg} / 100 \mathrm{ml}), \mathrm{MAO}(1.424 \pm 0.031 \mu / \mathrm{l})$, ascorbic acid $(54.50 \pm 0.408 \mathrm{mg} / 100 \mathrm{ml})$, protease $(1.700 \pm 0.034 \mu \mathrm{g} / 100 \mathrm{ml})$ and cysteine $(24.66 \pm 0.316 \mathrm{mg} / 100 \mathrm{ml})$. The mean values caused by ethanol extract of the bark were: total protein $(0.824 \pm 0.018 \mathrm{mg} / 100 \mathrm{ml})$, MAO $(1.374 \pm 0.045 \mu / \mathrm{l})$, ascorbic acid $(56.75 \pm 1.541 \mathrm{mg} / 100 \mathrm{ml})$, protease $(1.552 \pm 0.051 \mu \mathrm{g} / 100 \mathrm{ml})$ and cysteine $(25.07 \pm 0.469 \mathrm{mg} / 100 \mathrm{ml})$. The results of this study showed that both water and ethanol extracts were effective in promotion wound healing. However, the ethanol extracts of both the leaves and bark were more effective than those of water.
\end{abstract}

Keywords: Gambia albidum,total protein,monoamine oxidase, ascorcbic acid,protease,

\section{Introduction}

Traditional medicine can be defined as health practices, approaches, knowledge and beliefs in cooperating plant, animal and mineral-based medicine, spiritual therapies, manual techniques and exercised applied singularly or in combination to treat diagnose and prevent illness or maintain well-being (WHO, 2003).

Countries in Africa, Asia and Latin America use traditional medicine (TM) to help meet some of their primary needs. In Africa, up to $80 \%$ of the population use traditional medicine for primary health care. In industrialized countries, adaptations of traditional medicine are termed complementary or alternative medicine (CAM) (WHO, 2003).

In more recent years with considerable research, it has been found that many plants 20 indeed have maximal value and these plants have been used to make modern medicine which is now prescribed by physicians and available for purchase in pharmacy shops, the word "drug" is gotten from the Swinish word "drug" which react dried plant (WHO, 2003).

Medicinal plants are plants in which one or more of their organs contain substances that can be used for therapeutic purposes or which are precursors for the synthesis of useful drugs (WHO, 1991). The world Health Organization's consultative group that formulated this definition also states that such a description makes it possible to distinguish between medicinal plants whose therapeutic properties and constituents have been established scientifically and plants that are regarded as medicinal plants but which have not yet been subjected to scientific study (WHO, 1991). A number of plants have been used in traditional medicine for many years. Some do seem to work, although there may not be sufficient data (double blind trials for example) to confirm their efficacy (WHO, 1991). Finding healing powers in plants is an ancient idea. People in all continents have long used hundreds, if not thousands of indigenous plants for treatment of various ailments dating back to prehistory (Pieroni, 2000).

The accelerated use of and search for drugs and dietary supplements derived from plants by biochemist, pharmacologist, botanist and natural products chemist are combining the earth for phytochemicals 
and leads that could be developed for treatment of various diseases. In facts, many modern drugs have been derived from plants (Farnsworth, 1984). This began with the introduction of some active chemical drugs (like arsenic, copper sulphate, iron, etc.) followed by the rapid development of chemistry to the dominance of chemotherapychemical medicine as the orthodox system of the twentieth century (WHO, 1991).

In Nigeria, different medicinal plants are sometimes implicated in some herbal recipes for the treatment of different severe diseases. Some of the include: Aloe vera as laxative and purgative, ginger used as anti-metic, Garcinia kola used as diuretic and asthma, Occinumbasilicumas a cure for typhoid fever, garlic used as diuretic and vasodilator, Carica papaya used as a remedy for hypertension, Casamuscajan as a cure for small pox,Xyleopiaaethiopicas a remedy for dysentery,Chromolaenaodorata in healing wound, Piper guineeseas cure for rheumatism,Persea Americana as a remedy for dysentery, Cola nitidaused for the treatment of piles, Allium saliviumas a cure for malaria and thyme use as anti-cancer (FAO, 1984).

Nevertheless, research on most of the medicinal plants still thrives. Gambia albidum, commonly called in English white star apple (udara) belongs to a family of plant called Sapotaceace. It is cultivated in closed forest in the low land rain forest regions and distributed from Gambia, Sudan and Uganda to parts of South Africa. It is a plant whose leaf and bark have a characteristics bitter taste while the fruit has a characteristic sweet taste.Gambia albidumis used as source of food (fruit) and the bark and leaves are used in the treatment of cancer, stomach upset, dysentery, diarrhoea and haemorrhage.

The isolation of bioactive agents from plants can be grouped into two fundamental procedures viz:

a. Phytochemical which entails searching for active substances (ingredients) in plants or their extracts.

b. Biological screening which means searching for the physiological effect which a plant or its extracts produces (FAO, 1984).

However, wound is defines as injury to the skin caused by chemicals, cold, friction, heart, pressure and rays; and manifestation in the skin of internal condition, e.g. pressure, sores and ulcers (Nancy, 1987). Wound healing processed consist of integrated cellular and biochemical events leading to re-establishment of structural and functional integrity with regain of strength of injured tissue.

Ascorbic acid (Vitamin C) and a number of plant products (Kramer et al., 2006) have been reported by various workers, to possess prohealing effect. Wound healing herbals encourage blood clotting, fight infection and accelerate the healing of wound. The aqueous extract and the decoction from leaves of this plant have been used throughout Vietnam for the treatment of soft tissue wounds and burn wounds.

Ascorbic acid $\left(\mathrm{C}_{6} \mathrm{H}_{8} \mathrm{O}_{6}\right)$ is a water soluble vitamin that plays an anti-oxidative role in cellular metabolism (Kramer et al., 2006). It is easily oxidized and majority of it functions in vivo rely on this property. Vitamin C plays a key role in the body's synthesis of collagen and not epinephrine by keeping the enzymes responsible for these processes in their active reduced form (Kramer et al., 2006). Vitamin C is a co factor of poly-hydroxylase, an enzyme involved in the hydroxylation of praline residues of collagen. The hydroxylation confers stability and tensile strength upon collagen probably by the formation of three intermolecular hydrogen bonds that may involve bridging of water molecule (Williams et al., 1995). The entire process is crucial for contraction of wound during the proliferate and maturation phases of wound healing (Williams et al., 1995).

Proteinases ar those enzymes which are involved in the proteolytic processing of nascent polypeptide chain that accompany protein synthesis and extensive proteolysis resulting in degradation of protein to amino acids (Lynch et al., 1999). Proteinases are present in all wound exudates and play an essential role in the healing of acute and chronic wounds via cellular invasiveness, apoptosis and remodelling (Lynch et al., 1999). Collagenase is an example of protease that is responsible for degradation of excess collagen synthesized during wound healing (Lynch et al., 1999).

\subsection{AIMS / OBJECTIVES}

This research work investigates wound healing potentials of water and ethanol extracts of fresh leaves and barks of Gambia albidumin albino rats.

\section{MATERIALS}

\section{Materials And Method}

\section{BIOLOGICAL MATERIALS}

The biological samples used were:

Fresh leaves of Gambia albidum

Fresh barks of Gambia albidum

15 albino rats

Fresh leaves and barks of Gambia albidum (udara) were collected from a tree at Uburu in Ohaozara Local Government Area of Ebonyi state and used for the study. 


\section{ETHANOL EXTRACTION OF PLANT MATERIALS}

200g each of fresh leaves and barksGambia albidumwere extracted using ethanol by soaking both samples differently in $200 \mathrm{mls}$ of ethanol and allowed to stand overnight. They were filtered and squeezed using muslin clothes, the extracts were then concentrated using oven-drying method.

\section{WATER EXTRACTION OF PLANT MATERIALS}

$50 \mathrm{~g}$ each of fresh leaves and barks of Gambia albidumwere extracted using distilled water by soaking both samples differently in $100 \mathrm{mls}$ of distilled water and allowed to stand overnight. They were filtered and squeezed using muslin clothe.

\section{COLLECTION OF ANIMALS}

Fifteen albino rats weighing approximately 70 to $138 \mathrm{~g}$ were obtained from the Zoology Department in University of Nigeria, Nsukka. The rats were kept in three different cages (Group A, B and C) of six rats in groups $\mathrm{A}$ and $\mathrm{B}$ respectively and 3 rats in group $\mathrm{C}$ and allowed to acclimatize for seven days.

\section{DRUG FORMULATION \\ TOPICAL FORMATION}

The Gambia albidumleaves and barks extract formulation for topical administrations were prepared in the form of suspension by dissolving them in vegetable oil.

\section{WOUND CREATION}

The animals are anaesthetized with chloroform by open mast method. All the surgical intervention is carried out under sterile condition under general anaesthesia. The predetermined area for wound infliction at the back of the animal is prepared for surgery by removing hairs with razors.

The excision wounds are inflicted on the back which measures $2.0 \mathrm{~cm}$ (Nayak et al., 2007).

\section{DRUG ADMINISTRATION}

The route of administration is the topical application of the suspension to the wound area which was done twice daily - (morning and evening) after cleaning with sterile surgical cotton wool.

\section{EVALUATION OF WOUND HEALING}

Wound contraction, which contributes to wound closures, is expressed as a reduction in percentage of the original wound size is studied starting from the day of operation until the day of complete epithelisation and evaluated to calculate the degree of wound healing (Nayak et al., 2007).

The contraction or healing wound is evaluated or measured using tracing paper and metre rule in every two days interval until the wound is completely healed.

\section{ADMINISTRATION OF EXTRACTS TO THE ANIMALS}

The rats in Group A, numbers 1 to 3 were administered water extract of the bark while 4 to 6 were administered ethanol extract of the bark. The rats in Group B, numbers 1 to 3 were administered water extract of the leaves while 4 to 6 were administered ethanol extract o the leaves. The rats in Group C were not administered any of the extracts.

The various extracts were administered topically to the site of $2 \mathrm{~cm}$ wound of groups A and B while the control was treated with olive oil.

\section{COLLECTION OF SPECIMEN (BLOOD) FROM ANIMALS (ALBINO RATS)}

After about 10 days of topical administration of the extracts to the wound on the albino rats, they were starved overnight. Subsequently, blood samples were collected from them into sterile specimen bottles after decapitation while that needed for plasma preparation was collected in heparinized specimen bottle.

\section{PREPARATION OF SERUM}

The blood was centrifuged to 3,000Xg for 10 minutes and allowed to stand. The supernatant was collected using micropipette. 


\section{PREPARATION OF WORKING REAGENTS VITAMIN C STOCK STANDARD 160MG/ML VITAMIN C WORKING STANDARD}

2.5, 5.0, 7.5 and $10.0 \mathrm{ml}$ of the stock standard were pipetted into $100 \mathrm{ml}$ volumetric flasks and diluted to volume with anhydrous chloroform. ETHANOL, $95 \% \mathrm{~V} / \mathrm{V}$

$95 \mathrm{ml}$ of ethanol was measured using a $100 \mathrm{ml}$ cylinder followed by addition of $5 \mathrm{ml}$ of water, it was transferred to a leak - proof bottle and well mixed.

\section{N FOLIN REAGENT}

$10 \mathrm{ml}$ of $2 \mathrm{~N}$ folin reagents was mixed with $90 \mathrm{ml}$ of distilled water. This solution is stable for several months at room temperature if stored in an amber bottle.

\section{X LOWRY CONCENTRATE}

The reagent was prepared by mixing $30 \mathrm{ml}$ of copper reagent, $10 \mathrm{ml}$ of SDS solution and $10 \mathrm{ml}$ of $1 \mathrm{~m}$ solution of $\mathrm{NaOH}$. This concentration is stable for two to three weeks. If a white precipitate is formed, warm the solutions to $37^{\circ} \mathrm{C}$, if the precipitate is black, discard the solution.

\section{DETERMINATION OF PARAMETERS \\ DETERMINATION OF TOTAL PROTEIN}

The method of Lowry (1951) was applied, using Bovine Serum Albumin (BSA) as a standard. 0.4ml of serum was added to $0.4 \mathrm{ml}$ of $2 \mathrm{X}$ Lowry concentrate; this was incubated at room temperature $\left(37^{\circ} \mathrm{C}\right)$ for 10 minutes. $0.2 \mathrm{ml}$ of folin reagent was then pipetted into it, shaked to mix properly and incubated for an additional 30 minutes. Absorbance was read at 750nm against the blank (Renee and Joan, 1994).

\section{DETERMINATION OF PROTEINASES}

The method used here is based on the one described by Anison (1993). $0.1 \mathrm{ml}$ of the sample was added to $0.9 \mathrm{ml}$ of phosphate buffer and also $1 \mathrm{ml}$ of the substrate solution (serum) was added, mixed and using stopwatch at exactly 20 minutes, $3 \mathrm{ml}$ of 5\% TCA was added, mixed thoroughly and was allowed to stand for 30 minutes. It was centrifuged for 20 minutes and the absorbance was read at $280 \mathrm{~nm}$ against the blank.

\section{DETERMINATION OF ASCORBIC ACID (VITAMIN C) CONCENTRATION}

$0.5 \mathrm{ml}$ of heparinized plasma was added to $2.0 \mathrm{ml}$ of freshly prepared metaphosphoric acid $(6.0 \mathrm{~g} / 100 \mathrm{ml})$ is $13 \times 100 \mathrm{~nm}$ test tubes and mixed well on a vortex mixer. The mixture was centrifuged for 10 minutes at $2500 \mathrm{rpm}$. $1.2 \mathrm{ml}$ of each concentration of working standard was added into $13 \mathrm{x} 100 \mathrm{~nm}$ screwcap test tubes. $1.2 \mathrm{ml}$ of metaphosphoric acid was added to two test tubes for use as blanks. $0.4 \mathrm{ml}$ of dinitrophenyl hydrazine thiourea copper - sulphate reagent was added to all the test tubes. The tubes were capped, well - mixed and incubated in a water bath at $37^{\circ} \mathrm{C}$ for 3 hours, after the test tubes were removed from the water bath and chilled for 10 minutes in an ice bath and $2.0 \mathrm{ml}$ of cold sulphuric acid was added to all the test tubes. The absorbance was read at 520nm against blank.

\section{DETERMINATION OF MONOAMINE OXIDASE ACTIVITY}

$15 \mu$ mole of P- dimethylaminobenzylamine was added in a test tube containing $1.0 \mathrm{ml}$ of the sample after which 0.1M Potassium phosphate buffer was also added, this was incubated for 10 minutes in an ice bath and $2.0 \mathrm{ml}$ of cold sulphuric acid was added to all the test tubes. The absorbance was read at 520nm against the blank.

\section{DETERMINATION OF MONOAMINE OXIDASE ACITIVTY}

$15 \mu$ mole of P-dimethyaminobenzylamiine was added in a test tube containing $1.0 \mathrm{ml}$ of the sample after which $0.1 \mathrm{M}$ Potassium phosphate buffer was also added, this was incubated at $30^{\circ} \mathrm{C}$ for 1 hour. The reaction was stopped by the addition of $1.0 \mathrm{ml}$ of HCL. It was then centrifuged at $15,000 \mathrm{Xg}$ for 15 minutes. Absorbance was taken at 355nm against the blank. DETERMINATION OF CYSTEINE

$1.0 \mathrm{ml}$ of the sample was transferred into test tube and $5.0 \mathrm{mls}$ of 16 percent sodium acetate solution, $1.5 \mathrm{mls}$ of 12 percent acetic acid was added. 1 made up to $20 \mathrm{mls}$ with distilled water. Then mix and the absorbance were taken at 760nm after 5 minutes against blank. 
EXTRACTION YIELD

\section{Results}

PERCENTAGE YIELD OF EXTRACTS OF FRESH LEAVES OF Gambia albidum.

\begin{tabular}{|c|c|c|c|c|c|c|}
\hline $\mathrm{S} / \mathrm{N}$ & Solvent & $\begin{array}{l}\text { Initial mass of leaves } \\
\text { before extraction }(\mathrm{g})\end{array}$ & $\begin{array}{l}\text { Mass of leaves } \\
\text { after } \\
\text { extraction(g) }\end{array}$ & $\begin{array}{l}\text { Volume of } \\
\text { solvent added } \\
(\mathrm{ml})\end{array}$ & $\begin{array}{l}\text { Mass extract } \\
(\mathrm{g})\end{array}$ & $\begin{array}{l}\text { Percentage } \\
\text { yield of } \\
\text { extract }(\%)\end{array}$ \\
\hline 1. & Ethanol & 200 & 22.02 & 200 & 5 & 11.0 \\
\hline 2. & Distilled water & 50 & 15.05 & 100 & 4 & 20.3 \\
\hline
\end{tabular}

Table 4.1 shows the percentage yield of ethanol and distilled water extracts of fresh leaves of Gambia albidum.

\begin{tabular}{|c|c|c|c|c|c|c|}
\hline $\mathrm{S} / \mathrm{N}$ & Solvent & $\begin{array}{l}\text { Initial mass of leaves } \\
\text { before extraction }(\mathrm{g})\end{array}$ & $\begin{array}{l}\text { Mass of leaves } \\
\text { after } \\
\text { extraction(g) }\end{array}$ & $\begin{array}{l}\text { Volume of } \\
\text { solvent added } \\
(\mathrm{ml})\end{array}$ & $\begin{array}{l}\text { Mass extract } \\
(\mathrm{g})\end{array}$ & $\begin{array}{l}\text { Percentage } \\
\text { yield of } \\
\text { extract }(\%)\end{array}$ \\
\hline 1. & Ethanol & 200 & 27.98 & 6 & 6 & 14.0 \\
\hline 2. & Distilled water & 50 & 15.05 & 5 & 5 & 30.1 \\
\hline
\end{tabular}

Table 4.2 shows the percentage yield of ethanol and distilled water extracts of fresh leaves of Gambia albidum.

AVERAGE WEIGHTS OF THE ALBINO RATS USED FOR THE EXPERIMENT

\begin{tabular}{|l|l|l|}
\hline Group A $(\mathrm{g})$ & Group B $(\mathrm{g})$ & Group C $(\mathrm{g})$ \\
\hline $96.77 \pm 21.06$ & $103.7 \pm 12.05$ & $117.63 \pm 3.39$ \\
\hline
\end{tabular}

Values are mean \pm Standard Deviation

Table 4.3 shows the average weights of the albino rats used for the experi

PERCENTAGE WOUND REDUCTIONS IN WOUND DIAMETERS IN 10 DAYS OF TREATMENT.

GROUP $A_{1}$

WATER EXTRACT OF BARK

\begin{tabular}{lllllll}
\hline & Day 0 & Days 2 & 4 & 6 & 8 & 10 \\
Average Diameter (mm) & 24.87 & 24.73 & 22.73 & 20.07 & 15.90 & 8.63 \\
Average Percentage Reduction (\%) & 0 & 0.54 & 8.60 & 19.33 & 36.07 & 65.30
\end{tabular}

Table 4.4 above shows the average diameters $(\mathrm{mm})$ and average percentage reductions $(\%)$ of albino rats from day 2 to the $10^{\text {th }}$ day following treatment with water extracts of bark.

GROUP $\mathrm{A}_{2}$

WATER EXTRACT OF BARK

Average Diameter (mm)

$\begin{array}{llllll}\text { Day 0 } & \text { Days 2 } & 4 & 6 & 8 & 10 \\ 24.83 & 24.47 & 21.53 & 17.90 & 12.10 & 5.77 \\ 0 & 1.47 & 13.29 & 27.92 & 51.38 & 76.79\end{array}$

Average Percentage Reduction $(\%)$

0

$1.47 \quad 13.29$

$27.92 \quad 51.38$

76.79

Table 4.5 above shows the average diameters $(\mathrm{mm})$ and average percentage reductions $(\%)$ of albino rats from day 2 to the $10^{\text {th }}$ day following treatment with ethanol extracts of bark.

GROUP B 1

WATER EXTRACTS OF LEAVES

\begin{tabular}{lllllll}
\hline & Day 0 & Days 2 & 4 & 6 & 8 & 10 \\
Average Diameter (mm) & 24.83 & 24.67 & 23.90 & 22.50 & 19.70 & 11.43 \\
Average Percentage Reduction (\%) & 0 & 0.67 & 3.75 & 9.40 & 20.67 & 53.96 \\
\hline
\end{tabular}

Table 4.6 above shows the average diameters $(\mathrm{mm})$ and average percentage reductions $(\%)$ of albino rats from day 2 to the $10^{\text {th }}$ day following treatment with water extracts of leaf.

GROUP B , $_{2}$

WATER EXTRACTS OF LEAVES

Average Diameter (mm)

Day $0 \quad$ Days 24

Day 0

$24.90 \quad 24.03$

6

21.80

8

17.63

10

Average Percentage Reduction (\%)

0

1.06

4.62

13.49

30.03

9.87 
Table 4.7 above shows the average diameters $(\mathrm{mm})$ and average percentage reductions $(\%)$ of albino rats from day 2 to the $10^{\text {th }}$ day following treatment with water extracts of leaf.

\section{GROUP C \\ CONTROL}

\begin{tabular}{lllllll}
\hline & Day 0 & Days 2 & 4 & 6 & 8 & 10 \\
Average Diameter (mm) & 25.00 & 24.83 & 23.97 & 22.77 & 20.23 & 14.10 \\
Average Percentage Reduction (\%) & 0 & 0.67 & 4.13 & 8.94 & 19.07 & 43.60 \\
\hline
\end{tabular}

Table 4.8 above shows the average diameters $(\mathrm{mm})$ and average percentage reductions $(\%)$ of albino rats from day 2 to the $10^{\text {th }}$ day without treatment

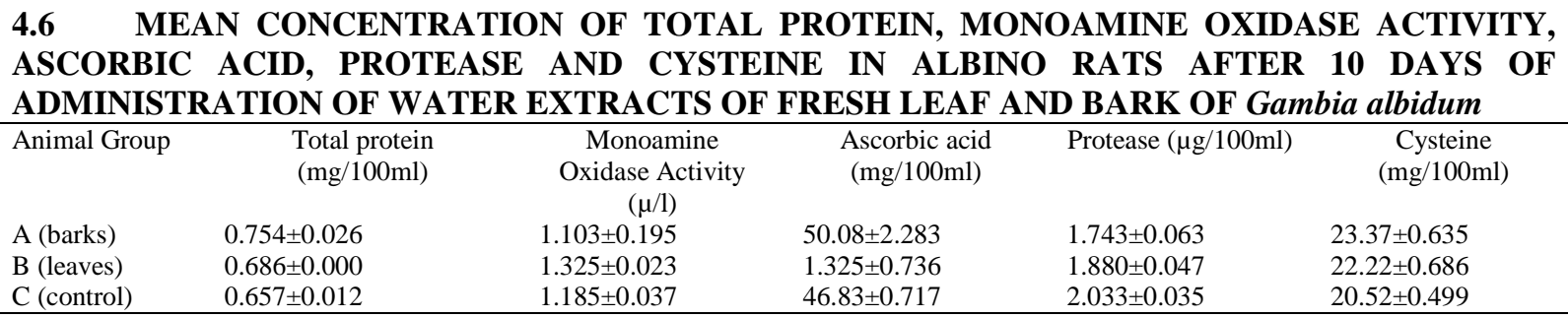

Values are mean \pm standard deviation, S.D.

Table 4.9 above shows that the levels of total protein, ascorbic acid, and cysteine in water extracts were found to be higher than the control.

While in protease, the level of the control is higher than the test. The table also shows that the level of monoamine oxidase activity in the water extract of leaves was found to be higher than the control.

4.6 MEAN CONCENTRATION OF TOTAL PROTEIN, MONOAMINE OXIDASE ACTIVITY, ASCORBIC ACID, PROTEASE AND CYSTEINE IN ALBINO RATS AFTER 10 DAYS OF ADMINISTRATION OF WATER EXTRACT OF FRESH LEAF AND BARK OF Gambia albidum

\begin{tabular}{lccccc}
\hline Animal Group & $\begin{array}{c}\text { Total protein } \\
(\mathrm{mg} / 100 \mathrm{ml})\end{array}$ & $\begin{array}{c}\text { Monoamine } \\
\text { Oxidase Activity } \\
(\mu / \mathrm{l})\end{array}$ & $\begin{array}{c}\text { Ascorbic acid } \\
(\mathrm{mg} / 100 \mathrm{ml})\end{array}$ & $\begin{array}{c}\text { Protease } \\
(\mu \mathrm{g} / 100 \mathrm{ml})\end{array}$ & $\begin{array}{c}\text { Cysteine } \\
(\mathrm{mg} / 100 \mathrm{ml})\end{array}$ \\
A (bark) & $0.824 \pm 0.018$ & $1.374 \pm 0.045$ & $56.75 \pm 1.541$ & $1.552 \pm 0.051$ & $25.07 \pm 0.469$ \\
B (leaves) & $0.767 \pm 0.012$ & $1.424 \pm 0.031$ & $54.50 \pm 0.408$ & $1.700 \pm 0.034$ & $24.66 \pm 0.316$ \\
C (control) & $0.657 \pm 0.012$ & $1.185 \pm 0.037$ & $46.83 \pm 0.717$ & $2.033 \pm 0.035$ & $20.52 \pm 0.499$ \\
\hline
\end{tabular}

Values are mean \pm standard deviation, S.D.

Table 4.9 above shows that the levels of total protein, ascorbic acid, and cysteine in water extracts were found to be higher than the control.

While in protease, the level of the control is higher than the test.

\section{Discussion}

The effects of water and ethanol extracts of Gambia albidum leaves and bark on wound healing were studied in albino rats inflicted with wounds. The extents of healing of the wounds were assessed within the ten days the wounds were treated topically with olive oil suspensions of the extracts. Relative to both the control and water treated rats, the ethanol extracts were observed to be more effective.

There was a reduction in the physical activities of the animals administered with the extracts of Gambia albidum. The observation may be as a result of the wound and reduced feed intake during the administration of the extracts. The mechanism for these reduced physical activities cannot be stated at this level of the research.

The percentage wound reductions in wound diameters after 1 day of treatment with both extracts of leaf and bark revealed that wound diameters $(\mathrm{mm})$ decrease progressively with continuous increase in percentage wound reductions (\%) from day 2 to the 1 th day in both groups of animals treated. The albino rats treated with ethanol extracts of leaf and bark have higher percentages of wound reductions than those treated with water extracts of leaf and bark.

The levels of total protein $(0.824 \pm 0.018)(0.67 \pm 0.012)$, monoamine oxidase activity $(1.374 \pm 0.045)$ (1.424 \pm 0.031$)$, ascorbic acid (56.75 \pm 1.541$)$ and cysteine (25.07 \pm 0.469$)(24.66 \pm 0.316)$ in ethanol extract of bark and leaf respectively were observed to be higher than the control. The water extracts; total protein $(0.754 \pm 0.026)$ 
(0.686 \pm 0.000$)$, ascorbic acid (50.08 \pm 2.383$)(51.50 \pm 0.736)$ and cysteine $(24.37 \pm 0.635)(22.22 \pm 0.686)$ of barks and leaves respectively were found to be higher than the controls.

The parameters encourage blood clotting and accelerate the healing of wounds. The chemical components of ethanol extracts may have contributed to this observation on their treatment to albino rats using aqueous and ethylacetate extracts fresh leaves of Raunolfiavomitoria.

The extract mechanism of wound healing by ethanol extracts of Gambia albidumleaves and barks could not be established at this stage of studies.

\section{Conclusion}

The observation made in this research have suggested that the ethanol extracts of fresh leaves and barks of the plant have greater wound healing potentials compared to the water extracts of the same plant.

\section{References}

[1]. Farnsworht, N.R. (1984). The Role of Medicinal Plants in Drug Development. Alfred Benzon Symposium Publishers, Denmark. 1730.

[2]. Food and Agricultural Organization (FAO) of the United Nations (1984). Some Medical Forest Plants of Africa and Latin America. 167:75-186

[3]. Krammer, B.K. Pultz, V.M. and McCormic, J.M. (2006). Vitamin C Analysis, Last Update 102-48-50.

[4]. Lynch, S.E. Colvin, R.B. and Antoniades, H.N. (1999). Growth Factors in Wound Healing. Journal of Clinical Investigation. 84:64643.

[5]. Nancy Roper (1987). Churchill Livingstone Medical Dictionary. $14^{\text {th }}$ edition. New York, USA. 282.

[6]. Nayak, S.B. Pereita, L.P. and Maharaji, D. (2007). Wound Healing Activity of Carica Papaya L in Experimentally Induced Diabetic Rats: Indian Journal of Experimental Biology. 45:739-743.

[7]. Pieroni, A. (2000). Medical Plants and Food Mediciens in Folk Traditions. African Journal of Ethnopharmacology, 70:235-273.

[8]. Rence, R. Alexander and Joan M. Ciriffiths (1994). Basic Biochemical Methods. $2^{\text {nd }}$ edition. Wiley-Liss Inci, New York, USA. 2829.

[9]. Williams, L., Leaper, D. And Carior, G.D. (1995). Antibiotics and Wound Healing. Medicine. 5:25-30.

[10]. World Health Organization (WHO) (1991). Traditional Medicine and Modern Health Care Progress Report by the Direct General World Health Organization. Document No A-144110.

[11]. World Health Organization (WHO) (2003). Principles of Traditional Medicine $8^{\text {th }}$ edition. American Press, New York. 124-126. 